\title{
Tanggung Jawab Notaris Dalam Pembuatan Akta Otentik Dengan Bahasa Asing
}

\author{
Arya Bagus Khrisna Budi Santosa Putra', I Made Dedy Priyanto ${ }^{2}$
}

${ }^{1}$ Program Studi Magister (S2) Kenotariatan, Fakultas Hukum Universitas Udayana,

E-mail: aryabagussantosa10@gmail.com

2Fakultas Hukum Universitas Udayana, E-mail: dedy_priyanto@unud.ac.id

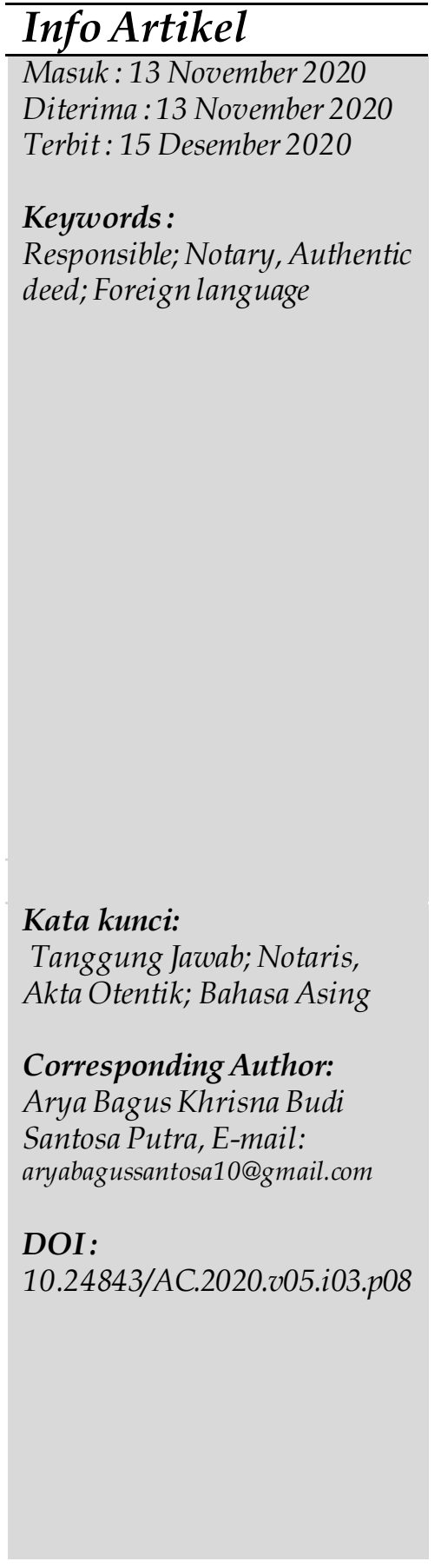

\begin{abstract}
In Law on the Occupation of Notary Article 43, there are 2 (two) contradicting Paragraphs, namely Paragraph (1) and Paragraph (3). In Paragraph (1) it is stated that "deeds must be made in Indonesian", while in Paragraph (3) it states "if the parties wish, the deed can be drawn up in a foreign language". The disharmony of the 2 (two) rules could potentially reduce the perfection of the deed. As for the problems raised in this study regarding what is the notary's responsibility in making authentic deeds in foreign languages? and what is the urgency of using Indonesian in making authentic deeds? Then the objective of this research is to knowing the Notary's responsibility in making authentic deeds in foreign languages and to find out how much urgency the use of Indonesian is in making authentic deeds. This study is using a normative research method with statutory approach. Through this research it is known that the responsibility of notaries in making authentic deeds in foreign languages can be classified into administrative, civil and criminal responsibilities, then it is known that the urgency of using Indonesian in making deeds is very important because the regulation of the applicatian of Indonesian in the territory of the Indonesian state is clearly stated in Article 36 of the 1945 Constitution of the Republic of Indonesia.
\end{abstract}

\begin{tabular}{l}
\hline Abstrak \\
\hline Pada Pasal 43 UUJN terdapat 2 (dua) Ayat yang bertolak \\
belakang yaitu dalam Ayat (1) dan Ayat (3). Pada Ayat (1) \\
dinyatakan bahwa "aktawajib dibuat dalam bahasa indonesia", \\
sedangkan dalam Ayat (3) dinyatakan "jika para pihak \\
menghendaki, akta dapat dibuat dalam bahasa asing". \\
Ketidakharmonisan dari2 (dua) aturan tersebut dapatberpotensi \\
untuk mengurangi kesempurnaan akta. Adapun permasalahan \\
yang diangkatdalampenelitianini mengenai apakah tanggung \\
jawab Notaris dalam pembuatan akta otentik dengan bahasa \\
asing? dan bagaimana urgensi penggunaan bahasa Indonesia \\
dalam pembuatan akta otentik? Lalu tujuan dari adanya \\
penelitianini ialah untuk mengetahui apakah bentuk tanggung \\
jawab Notaris dalam pembuatan akta otentik dengan bahasa \\
asing danuntuk mengetahui seberapa besar urgensipenggunaan \\
bahasa Indonesia dalam pembuatan akta otentik. Metode pada \\
penelitian ini adalah metode penelitian normatif dengan \\
menggunakan pendekatan perundang-undangan. Melalui \\
penelitian ini diketahui bahwa tanggung jawab Notaris dalam
\end{tabular}


pembuatan akta otentik dengan bahasa asing dapat diklasifikasikan menjadi tanggungjawab administratif, perdata dan pidana, lalu diketahuiurgensi penggunaan bahasa Indonesia dalam pembuatan akta sangatlah penting karena pengaturan penggunaan bahasa Indonesia dalam wilayah negara Indonesia telah termuat jelas dalam Pasal 36 Undang-Undang Dasar Negara Republik Indonesia tahun 1945.

\section{Pendahuluan}

Pada dasarnya perjanjanjian bisa dilakukan secara lisan ataupun tertulis. Pada kaitannya dengan perjanjian tertulis, suatu perjanjian dilakukan dengan menuangkannya dalam bentuk tertulis, sedangkan perjanjian lisan merupakan bentuk kesepakatan para pihak yang dilaksanakan melalui perkataan yang sifatnya lisan. Pada prakteknya perjanjian tertulis sendiri mencakup 2 (dua) jenis, yang pertama adalah perjanjian di bawah tangan serta perjanjian notariil/akta otentik yang mana diartikan sebagai "suatu akta yang dibuat dalam bentuk yang ditentukan undang-undang oleh atau di hadapan pejabat umum yang berwenang untuk itu di tempat akta itu dibuat".

Penjelasan UUJN juga memberikan kepastian pada Notaris bahwa Notaris perlu mendapatkan jaminan perlindungan dalam peranannya menjalankan tugas sebagai pejabat publik. Bagaimanapun juga produk akta yang dihasilkan Notaris selalu dianggap bersifat otentik selama belum bisa dibuktikan sebaliknya.

Dalam menjalankan kepastian hukum serta jaminan perlindungan bagi pelaksanaan tugas Notaris harus selaras dengan keterbaharuan kebutuhan masyarakat maupun perkembangan aturan hukum. Sebagai pengemban jabatan, Notaris sepatutnya menjalankan tugasnya sesuai apa yang diamanatkan dari undang-undang. Penyusunan akta harus merujuk kepada Undang-Undang Nomor 2 Tahun 2014 tentang Perubahan Atas Undang-Undang Nomor 30 Tahun 2004 tentang Jabatan Notaris (selanjutnya disingkat UUJN) Pasal 38 sampai Pasal 53. Ketentuan dimaksud memberikan batasanbatasan dan petunjuk-petunjuk bagaimana seorang Notaris melakukan kewajiban dengan baik dan benar.

Dilihat dari ketentuan Pasal 43 UUJN terdapat inkonsistensi antara Ayat yang satu dengan Ayat lainnya. Hal ini menandakan terdapat ketidaktegasan antar Ayat dalam pasal yang sama dalam UUJN dimana pada Pasal 43 Ayat (1) mengharuskan penggunaan bahasa Indonesia dalam penyusunan akta sedangkan pada Pasal 43 Ayat (3) membolehkan Notaris menyusun akta menggunakan bahasa selain bahasa Indonesia apabila dikehendaki oleh para pihak.

Pengunaan bahasa Indonesia pada wilayah hukum Republik Indonesia merupakan bentuk nyata kedaulatan negara. Bila di dalam wilayah hukum Republik Indonesia diperbolehkan untuk mempergunakan bahasa selain bahasa Indonesia dalam penyusunan akta otentik tentunya akan menghilangkan esensi dari penggunaan bahasa nasional itu sendiri. Setiap negara tentu menghendaki agar bahasa nasionalnya dikenal secara internasional dan berdaulat di dalam negaranya. 
Kewajiban untuk menjelaskan dan menterjemahkan isi suatu akta berbahasa asing pada dasarnya sudah diatur dalam Pasal 43 Ayat (2) UUJN. Hal tersebut menunjukan inefisiensi dari pembuatan akta dengan bahasa asing. Apabila Notaris membuat akta berbahasa Indonesia lalu menerjemahkannya maka hal tersebut tentu lebih dapat mengurangi adanya kecacatan dalam pemaknaan bahasa dalam akta dan juga secara filosofis dapat menempatkan bahasa Indonesia sebagai bahasa utama.

Perbedaan interpretasi dalam menerjemahkan akta berbahasa asing tentunya sulit untuk dihindari sehingga dapat menjadikan Notaris sebagai pihak yang ikut bertanggungjawab apabila nantinya timbul kerugian dari para pihak karena perbedaan interpretasi istilah asing pada akta. Dalam menjalankan kewenangannya Notaris memang dilindungi oleh undang-undang akan tetapi bila Notaris menimbulkan kerugian bagi klien atau para penghadap dalam menjalankan jabatannya, Notaris dapat dimintakan ganti kerugian oleh pihak yang merasa dirugikan. ${ }^{1}$

Kapabilitas Notaris dalam menyusun akta otentik melahirkan tanggung jawab penuh terhadap bagi dirinya terhadap semua produk hukum yang ia buat. Oleh karenanya dalam penyusunan akta autentik Notaris mengikuti syarat formil maupun materil. Tanggung jawab Notaris terhadap aktanya terdapat didalam Pasal 65 UUJN. Dalam Pasal 65 UUJN tersebut menentukan bahwa "segala akta yang dibuat menjadi tanggungjawab Notaris, Notaris pengganti sementara maupun Notaris pengganti". Tanggungjawab dalam akta tersebut tetap dimiliki oleh si Notaris walaupun protokolnya sudah diberikan pada pihak yang selanjutnya menyimpan protokol Notaris tersebut. Tanggungjawab Notaris dimulai dari awal pembuatan akta sampai dengan akhir pembuatan akta. Apabila merujuk kepada UUJN tidak ditentukan secara jelas mengenai pertanggungjawaban Notaris terhadap penyusunan akta menggunakan berbahasa asing. Permasalahan yang pertama pada penelitian ini mengenai bentuk tanggung jawab Notaris perihal penyusunan akta berbahasa asing apabila terdapat kesalahan pemaknaan istilah asing oleh Notaris. Permasalahan kedua terkait dengan urgensi penyusunan akta otentik dengan bahasa Indonesia. Selain bertujuan untuk mengetahui bentuk tanggung jawab Notaris serta seberapa besar urgensi penyusunan akta otentik dengan bahasa Indonesia, penelitian ini juga bertujuan memberikan paradigma tentang kemudahan dan efisiensi yang dapat dinikmati oleh Notaris maupun para penghadap apabila memilih menyusun akta otentik dengan bahasa Indonesia.

Sebelum penelitian ini dibuat, telah terbit tesis dengan judul "Pertanggungjawaban Notaris Terhadap Perbedaan Interpretasi Akta Yang Menggunakan Bahasa Asing" oleh Melani Kristina Pasaribu yg membahas mengenai "kewenangan Notaris dalam hal pembuatan akta dalam bahasa asing dan mengenai tanggung jawab Notaris terhadap perbedaan interpretasi akta antara akta yang menggunakan bahasa Indonesia dengan akta yang menggunakan bahasa asing". Terdapat pula penelitian yang berjudul "Prinsip Kepastian Hukum Akta Notaris yang Dibuat dalam Bahasa Asing" oleh Christian Nugrahadi yang membahas mengenai "mutt Pasal 43 UUJN memperbolehkan Akta Notaris dibuat dalam bahasa asing serta siapa yang memiliki otoritas menilai atau

${ }_{1}^{1}$ Widyantari, M. D. (2019). Fungsi dan Kedudukan Penerjemah Tersumpah dalam Pembuatan Akta Notaris. Acta Comitas: Jurnal Hukum Kenotariatan, 4(1), 34-44, DOI: 10.24843/AC.2019.v04.i01.p04, p. 35 
menafsirkan klausula akta yang dibuat dalam bahasa asing jika terjadi permasalahan hukum". Kedua penelitian tersebut memiliki fokus yang berbeda dengan artikel ini karena di dalam artikel ini lebih berfokus pada pentingnya menggunakan bahasa Indonesia dalam menyusun akta yang secara langsung dapat mempermudah tugas dari Notaris dan dapat meminimalisir tanggung jawab yang timbul nantinya bagi Notaris terkait dengan akta yang dibuat. Penelitian ini sendiri dikaji secara filosofis dan menggunakan teori peraturan perundang-undangan yang masih dipandang relevan.

\section{Metode Penelitian}

Bertumpu pada pendekatan perundang-undangan membuat penelitian ini dikaji dengan metode penelitian hukum normatif. Hal tersebut memiliki maksud untuk mengukur konsistensi dan kesesuaian suatu peraturan hukum baik dengan aturan berbeda maupun aturan-aturan dalam suatu lingkup undang-undang yang sama. Hasil yang didapat dari proses tersebutlah yang nantinya dapat digunakan untuk membentuk suatu argumentasi guna memudahkan pemecahan masalah pada jurnal ini. ${ }^{2}$ Bahan hukum primer serta sekunder merupakan sumber dari penelitian ini. Aturan hukum yang terkait dengan permasalahan yang diangkat dipergunakan sebagai bahan hukum utama lalu kumpulan buku/literatur dan jurnal menjadi bahan hukum sekundernya. ${ }^{3}$ Selanjutnya digunakan teknik sistem kartu dalam pengumpulan bahan hukum. Teknik sistem kartu ini yaitu dengan mengumpulkan bahan-bahan kemudian mencatat informasi penting terkait masalah dalam jurnal ini . Setelah terkumpul lalu dipaparkan dengan terbuka suatu kondisi maupun peristiwa hukum yang terjadi melalui teknik deskriptif.

\section{Hasil Dan Pembahasan}

\subsection{Tanggung Jawab Notaris Dalam Pembuatan Akta Otentik Dengan Bahasa Asing}

Dalam menjalankan suatu jabatan,Notaris memiliki kewenangan yang melekat dalam jabatannya. Kewenangan yang terdapat dalam jabatannya ini melahirkan suatu pertanggungjawaban, sesuai terhadap prinsip "gee bevoegheid zonder verantwoordelijkheid" yaitu tiada kewenangan tanpa pertanggungjawaban".4

Segala bentuk wewenang yang didapatkan dari jabatan apapun tentunya memiliki sumber. Terdapat 3 (tiga) jenis wewenang yang dikenal pada hukum administrasi yaitu delegasi, mandat, dan atribusi. Atribusi merupakan wewenang yang timbul dari peraturan perundang-undangan yang sifatnya baru dan datang langsung dari aturan hukum. Wewenang yang didapatkan secara delegasi dapat diartikan sebagai pengalihan wewenang yang mana didasari oleh aturan hukum. Mandat pada dasarnya bukan merupakan suatu pemindahan maupun pengalihan wewenang, namun dikarenakan yang memiliki kewenangan tidak dapat melaksanakan wewenangnya pada saat itu oleh

\footnotetext{
2 Peter Mahmud Marzuki. (2011). Penelitian Hukum (Edisi revisi). Cetakan ketujuh. Jakarta: Prenadamedia Group, p. 133

${ }^{3}$ Ibid., p. 181

${ }^{4}$ Ridwan H.R. (2014). Hukum AdministrasiNegara: Edisi Revisi. Jakarta:Grafindo Persada, p. 334
} 
karena itu wewenang tersebut di kuasakan. Notaris sendiri merupakan jabatan yang memiliki kewenangan atribusi karena bersumber langsung dari UUJN itu sendiri. ${ }^{5}$

Pembuatan akta oleh seorang Notaris wajib merujuk pada bab VII UUJN, Pasal 38 sampai dengan Pasal 53 UUJN. Ketentuan sebagaimana dimaksud memberikan batasanbatasan dan petunjuk petunjuk bagaimana seorang Notaris melakukan kewajibannya dengan benar, namun dalam UUJN sendiri terdapat ketidaktegasan antar Ayat dalam satu pasal yang sama dalam Pasal 43 UUJN. Dalam Pasal 43 Ayat (3) mengatur, "jika para pihak menghendaki, Akta dapat dibuat dalam bahasa asing", sedangkan dalam Ayat (1) diatur bahwa "akta wajib dibuat dalam bahasa indonesia". Melihat dari rumusan pasal tersebut tentu memberikan pandangan apabila Notaris membuat akta tidak dalam bahasa Indonesia, Notaris tersebut melanggar syarat keabsahan akta mengenai bentuknya atau lebih dikenal dengan syarat formil. Sehingga secara langsung mengurangi kekuatan pembuktian akta tersebut.

Menurut Vegting dan Kranenburg ada 2 (dua) teori yang mendasari bentuk yakni "teori fautes personalles yang menjelaskan bahwa kerugian yang dialami oleh pihak ketiga dapat dibebankan pada pejabat yang berwenang bila mana melalui kewenangannya tersebut telah menimbulkan kerugian. Pembebanan tanggung jawab pada teori ini menitiberatkan pada pertanggungjawaban pejabat sebagai natuurlijk persoon. Lelu menurut teori fautes de services menyatakan bahwa kerugian yang diderita oleh pihak ketiga dapat dibebankan kepada pejabat yang berwenang dari instansinya". Sehingga dari teori ini diketahui bahwa pertanggungjawaban dibebankan langsung terhadap jabatan dari pejabat tersebut. Tanggung jawab Notaris dapat dikatakan sejalan dengan Teori Fautes Personalles oleh Vegtug dan Kranenburg, karena Notaris menjalankan kewenangan berdasarkan suatu jabatan yang diatur dalam UUJN.6 Kewenangan serta tanggung jawab Notaris lahir dari adanya UUJN. Saat seseorang diangkat sebagai Notaris dan telah melalui sumpah jabatan maka pada saat itu juga segala tugas dan tanggung jawab jabatan Notaris melekat pada dirinya dan ia diwajibkan untuk melaksanakan tugas-tugasnya berdasarkan undang-undang berlaku. ${ }^{7}$

Seperti yang telah dijelaskan sebelumnya mempersamakan pemaknaan dalam bahasa tertentu terutama bahasa asing selain bahasa Indonesia dapat menjadi suatu masalah. Terutama untuk Notaris yang tidak fasih dalam berbahasa asing, hal tersebut dapat memicu multitafsir dalam suatu pemaknaan kata tertentu. Tanggung jawab seorang Notaris muncul pada saat ia bertindak membuat akta otentik dengan tidak mengikuti pedoman UUJN.

\footnotetext{
${ }^{5}$ Ghansham Anand. (2018). Karakteristik Jabatan Notaris di Indonesia. Jakarta: Prenadamedia Group, p. 38

${ }^{6}$ Ridwan H.R. Op. Cit., p. 336

7 Pertiwi, S. M., Sirtha, I. N., \& Dharsana, I. M. P. Tanggung Jawab Notaris Terhadap Akta Otentik Yang Berakibat Batal Demi Hukum Pada Saat Berakhir Masa Jabatannya. Acta Comitas: Jurnal Hukum Kenotariatan, 247-257, DOI: https://doi.org/10.24843/ AC.2017.v02.i02.p09, p. 250
} 
Tanggung jawab Notaris tersebut dapat diklasifikasikan dalam berbagai segi hukum seperti: tanggung jawab secara administrasi, perdata dan pidana yang dapat dijelaskan sebagai berikut: ${ }^{2}$

a. Tanggung jawab secara administrasi

Secara administrasi Notaris bertanggung jawab bila terdapat pelanggaran sebagaimana ditentukan dalam Pasal 85 UUJN. Dalam Pasal 85 UUJN menentukan sanksi administratif terkait melakukan pelanggaran yang terdapat didalam Pasal tersebut. ${ }^{9}$ Penerapan sanksi terhadap Notaris atas pelanggaran tersebut dapat dalam bentuk teguran secara lisan maupun tertulis, atau dapat juga dikenakan sanksi pemberhentian tugas sementara. Sampai pada pemberhentian permanen yang dilaksanakan baik dengan hormat maupun tidak hormat.

b. Tanggung jawab secara perdata

Notaris dapat dimintai pertanggungjawaban secara perdata apabila melakukan suatu pelanggaran yang merugikan bagi para pihak yang terikat dalam akta yang dibuatnya. Sanksi dapat berupa ganti rugi maupun beserta bunga, penggantian biaya dan segala hal yang merupakan akibat pelanggaran yang dilakukan oleh Notaris sebagai natuurlijk persoon yang menyebabkan akta para pihak berubah menjadi akta dibawah tangan sebagaimana dimaksud Pasal 84 UUJN.10

\section{c. Tanggung jawab secara pidana}

Apabila ditemukan fakta bahwa Notaris dalam proses penyusunan aktanya terbukti secara sengaja dengan itikad buruk melanggar ketentuan UUJN demi kepentingan pribadi maupun pihak tertentu maka ia dapat dimintai pertanggungjawaban secara pidana. Dalam hal ini Notaris tidak dapat lagi dilindungi dengan ketentuan UUJN melainkan harus bertanggungjawab secara pidana dibawah ketentuan Pasal 266 KUHP yang mengatur bahwa siapapun yang meminta atau memasukkan keterangan palsu, dalam hal ini adalah segala bentuk keterangan baik secara lisan mapun tertulis yang mengandung unsur ketidak benaran yang seolah-olah benar yang kemudian sengaja dipergunakan di dalam pembuatan akta autentik. Ancaman pidana tersebut berlaku sama jika siapapun dengan sengaja menggunakan akta tersebut sehingga menyebabkan suatu kerugian terhadap orang lain. ${ }^{11}$

8 Afifah, K. (2017). Tanggung Jawab dan Perlindungan Hukum bagi Notaris secara Perdata Terhadap Akta yang Dibuatnya. Lex Renaissance, 2(1), 147-161, DOI: https://doi.org/10.20885/JLR.vol2.iss1.art10, p. 151

${ }^{9}$ Trisnasari, I. G. A. O. (2019). Tanggungjawab Notaris Terhadap Penomoran Ganda Pada Akta Yang Berbeda. Acta Comitas: Jurnal Hukum Kenotariatan, 4(1), 99-108, DOI: 10.24843/AC.2019.v04.i01.p09, p. 104

10 Setiabudhi, I. K. R., \& Swardhana, G. M. (2017). Sanksi Hukum Terhadap Notaris Yang Melanggar Kewajiban Dan Larangan Undang-Undang Jabatan Notaris. Acta Comitas: Jurnal Hukum Kenotariatan, 110-121, DOI: https:// doi.org/10.24843/ AC.2017.v02.i01.p10, p. 114

${ }_{11}$ Mahendra, M. C. A. Akibat Hukum Terhadap Kesalahan Ketik pada Akta yang Dibuat Notaris. Acta Comitas: Jurnal Hukum Kenotariatan, 4(2), 227-236, DOI: 10.24843/ AC.2019.v04.02.p.06, p. 232 


\subsection{Urgensi Penggunaan Bahasa Indonesia Dalam Pembuatan Akta Otentik}

Pasal 43 Ayat (3) UUJN mengatur "jika para pihak menghendaki, akta dapat dibuat dalam bahasa asing." Ketentuan pasal tersebut merupakan ketentuan pengecualian dari ketentuan "akta wajib dibuat dalam bahasa indonesia" yang terdapat pada Ayat (1). Rumusan pasal tersebut menjadi sangat bertolak belakang dengan rumusan pasal sebelumnya, hal ini tentu menunjukan adanya pertentangan norma di dalam satu perundang-undangan yang sama. Pertentangan tidak hanya terdapat pada UUJN, dalam Undang-Undang Dasar Negara Republik Indonesia (selanjutnya disebut UUD 1945) pada Pasal 36 mengatur "Bahasa negara adalah bahasa Indonesia". Hal itu menunjukan UUD 1945 menghendaki dalam kegiatan berbangsa dan bernegara dihubungkan memalui bahasa Indonesia termasuk dalam kegiatan hubungan hukum, sedangkan dalam Pasal 43 Ayat (3) UUJN tidak mencerminkan tujuan tersebut.

Rumusan Pasal 43 Ayat (3) UUJN jelas menunjukan ketidakharmonisan dengan maksud serta tujuan norma konstitusional yakni UUD 1945. Asas "lex superior derogat legi inferior" tentu tepat digunakan sebagai dasar berfikir dalam permasalahan di penelitian ini, karena asas tersebut memberikan pedoman bahwa ketentuan dalam suatu aturan dapat mengesampingkan aturan yang tingkatan hirarkinya lebih rendah. Berbicara mengenai hirarki perundang-undangan tentu tidak terlepas dari teori Stufenbeau oleh Hans Kelsen. Ia menyatakan bahwa peraturan di dalam sistem hukum memiliki jenjang atau hirarki, yang mana peraturan hukum dengan drajat lebih rendah wajib mengikuti kaidah aturan diatasnya dan peraturan hukum tersebut juga harus berpegang pada aturan hukum konstitusi (UUD 1945). Aturan konstitusi juga harus berdasar pada norma dasar/groundnorm dalam hal ini Pancasila sebagai dasar negara. ${ }^{12}$

Bila melihat dari teori tersebut, ketentuan dari Pasal 43 Ayat (3) UUJN tidak dapat bertolak belakang dengan ketentuan Pasal 36 UUD 1945. Bila itu terjadi maka akan timbul ketidakharmonisan tujuan dari aturan hukum negara itu sendiri, karena aturan hukum tidak serta merta disusun untuk mengatur kehidupan masyarakat saja namun juga untuk menuntun suatu cita-cita maupun tujuan dari suatu masyarakat. Salah satunya penggunaan bahasa Indonesia untuk sarana komunikasi yang utama dan resmi serta sarana melakukan hubungan hukum di Indonesia.

Pada dasarnya penggunaan bahasa dalam akta bukan merupakan permasalahan yang tanpa jalan keluar, karena dalam UUJN sendiri telah diatur mengenai hal tersebut bahwa "dalam hal penghadap tidak mengerti bahasa yang digunakan dalam akta, Notaris wajib menerjemahkan atau menjelaskan isi akta itu dalam bahasa yang dimengerti oleh penghadap". Ketentuan itu tentunya dapat digunakan apabila penghadap yang ingin membuat akta di Notaris tidak memahami bahasa Indonesia, sehingga mengurangi urgensi penyusunan akta berbahasa asing.

Tidak semua Notaris memiliki kemampuan dalam penggunaan dan pemaknaan bahasa asing, terlebih dalam konteks ini bahasa asing yang dimaksud tidak terbatas hanya pada bahasa Inggris sebagai bahasa internasional. Oleh karenanya dalam Pasal 43 Ayat (5)

12 Samekto, F. A. (2019). Menelusuri Akar Pemikiran Hans Kelsen Tentang Stufenbeautheorie Dalam Pendekatan Normatif-Filosofis. Jurnal Hukum Progresif, 7(1), 1-19, DOI: https://doi.org/10.14710/hp.7.1.1-19, p. 5 
UUJN ditentukan "apabila Notaris tidak dapat menerjemahkan atau menjelaskannya, akta tersebut diterjemahkan atau dijelaskan oleh seorang penerjemah resmi".

Perihal akta tersebut diterjemahkan secara lisan maka pada bagian penutup akta diberikan keterangan bahwa akta telah diterjemahkan dan dijelaskan kepada para penghadap dikarenakan para penghadap tidak memahami bahasa Indonesia. Dalam hal akta diterjemahkan oleh penerjemah resmi maka dalam penutup akta juga diberikan keterangan hal tersebut dan akta juga dibubuhi tanda tangan penerjemah resmi. Sama halnya dengan penerjemahan secara tertulis, penambahan keterangan dalam penutup akta juga diperlukan. Bedanya di dalam keterangannya disebutkan bahwa terjemahan dari akta tersebut telah dibuat secara tertulis pada lembar atau dokumen terpisah. Terkait terjemahaan akta yang dilakukan oleh penerjemah resmi juga diberikan keterangan yang sama dan ditambah dengan pembubuhan tanda tangan penerjemah resmi tersebut pada akta.

Penggunaan bahasa Indonesia sangatlah penting dalam segala bentuk aspek kehidupan masyarakat. Terlebih dalam penyusunan suatu akta otentik oleh Notaris, karena pemaknaan setiap kosa kata yang ada dalam bahasa Indonesia tidak serta merta dapat dimaknai ke dalam bahasa asing. Notaris sendiri memiliki tanggung jawab yang sangat besar untuk menghasilkan suatu produk hukum yang sesuai dengan keinginan penghadap. Tanggung jawab tersebut mewajibkan Notaris memiliki sifat ketelitian dan kecermatan pada setiap tahapan pembuatan akta yang dimulai dari menkonstantir, mengkualifisir, dan menkonstituir suatu peristiwa. ${ }^{13}$

Notaris sudah seharusnya mengutamakan penggunaan bahasa Indonesia di dalam pembuatan aktanya guna mendukung penyusunan akta yang cermat dan tanpa cela, karena bagaimanapun juga bahasa Indonesia merupakan bahasa ibu bagi para warga negara indonesia. Tentunya Notaris yang sejak awal memang diharuskan berkewarganegaraan Indonesia (seuai dengan Pasal 3 huruf a UUJN) akan lebih mudah menciptakan produk hukum yang sempurna tanpa cacat secara formal bila menggunakan bahasa nasionalnya sendiri.

Dalam bagian menimbang Undang-Undang Nomor 24 Tahun 2009 tentang Bendera, Bahasa dan Lambang Negara serta Lagu Kebangsaan juga disebutkan pada huruf a "bahwa bendera, bahasa, dan lambang negara, serta lagu kebangsaan Indonesia merupakan sarana pemersatu, identitas, dan wujud eksistensi bangsa yang menjadi simbol kedaulatan dan kehormatan negara sebagaimana diamanatkan dalam UUD 1945". Setiap bangsa memang pada dasarnya ingin menunjukan kedaulatan dan eksistensinya terlebih dalam penggunaan bahasa nasional. Bila melihat landasan filosofis yang terdapat pada huruf a bagian menimbang tersebut, maka sudah jelas bahwa urgensi penggunaan bahasa indonesia memanglah penting dan harus lebih ditekankan terutama pada dokumen resmi seperti akta otentik.

\section{Kesimpulan}

Tanggung jawab Notaris dapat timbul apabila Notaris lalai dalam menyampaikan terjemahan akta berbahasa asing yang dapat menimbulkan kerugian bagi para pihak, baik dengan sengaja maupun tidak disengaja. Tanggung jawab tersebut diklasifikasikan

${ }^{13}$ Achmad Ali. (2011). Menguak Tabir Hukum. Bogor: Ghalia Indonesia, p. 120. 
dalam berbagai segi yaitu melalui tanggung jawab secara administrasi, perdata serta pidana. Urgensi penggunaan bahasa Indonesia dalam penyusunan akta otentik sangatlah penting, mengingat landasan filosofis penggunaan bahasa Indonesia sendiri adalah sebagai wujud eksistensi dan kedaulatan bangsa Indonesia. Selain itu penggunaan bahasa Indonesia telah secara jelas diatur dalam Pasal 36 UUD 1945 sehingga aturan yang dibawahnya harus menyesuaikan terhadap aturan tersebut. Guna menghindari adanya kecacatan dalam penafsiran akta sebaiknya akta tetap dibuat dengan bahasa Indonesia.

\section{Daftar Pustaka}

\section{$\underline{\text { Buku }}$}

Achmad Ali. (2011). Menguak Tabir Hukum. Bogor: Ghalia Indonesia.

Ghansham Anand. (2018). Karakteristik Jabatan Notaris di Indonesia. Jakarta: Prenadamedia Group.

Peter Mahmud Marzuki. (2011). Penelitian Hukum: Edisi revisi. Cetakan ketujuh, Jakarta: Prenadamedia Group.

Ridwan H.R. (2014). Hukum Administrasi Negara: Edisi Revisi. Jakarta: Grafindo Persada.

\section{Jurnal}

Afifah, K. (2017). Tanggung Jawab dan Perlindungan Hukum bagi Notaris secara Perdata Terhadap Akta yang Dibuatnya. Lex Renaissance, 2(1), 147-161, DOI: https://doi.org/10.20885/JLR.vol2.iss1.art10

Mahendra, M. C. A. Akibat Hukum Terhadap Kesalahan Ketik pada Akta yang Dibuat Notaris. Acta Comitas: Jurnal Hukum Kenotariatan, 4(2), 227-236, DOI: 10.24843/AC.2019.v04.02.p.06

Pertiwi, S. M., Sirtha, I. N., \& Dharsana, I. M. P. Tanggung Jawab Notaris Terhadap Akta Otentik Yang Berakibat Batal Demi Hukum Pada Saat Berakhir Masa Jabatannya. Acta Comitas: Jurnal Hukum Kenotariatan, 247-257, DOI: https://doi.org/10.24843/AC.2017.v02.i02.p09

Samekto, F. A. (2019). Menelusuri Akar Pemikiran Hans Kelsen Tentang Stufenbeautheorie Dalam Pendekatan Normatif-Filosofis. Jurnal Hukum Progresif, 7(1), 1-19, DOI: https://doi.org/10.14710/hp.7.1.1-19

Setiabudhi, I. K. R., \& Swardhana, G. M. (2017). Sanksi Hukum Terhadap Notaris Yang Melanggar Kewajiban Dan Larangan Undang-Undang Jabatan Notaris. Acta Comitas: Jurnal Hukum Kenotariatan 110-121, DOI: https://doi.org/10.24843/AC.2017.v02.i01.p10

Trisnasari, I. G. A. O. (2019). Tanggungjawab Notaris Terhadap Penomoran Ganda Pada Akta Yang Berbeda. Acta Comitas: Jurnal Hukum Kenotariatan, 4(1), 99-108, DOI: 10.24843/AC.2019.v04.i01.p09

Widyantari, M. D. (2019). Fungsi dan Kedudukan Penerjemah Tersumpah dalam Pembuatan Akta Notaris. Acta Comitas: Jurnal Hukum Kenotariatan, 4(1), 34-44, DOI: 10.24843/AC.2019.v04.i01.p04

\section{Peraturan Perundang-Undangan}

Indonesia. Undang-Undang Dasar Negara Republik Indonesia Tahun 1945

Indonesia. Undang-Undang Republik Indonesia Nomor 30 Tahun 2004 tentang Jabatan Notaris. Lembaran Negara Republik Indonesia Tahun 2004 Nomor 117. Tambahan Lembaran Negara Republik Indonesia Nomor 4432 
Indonesia. Undang-Undang Republik Indonesia Nomor 2 Tahun 2014 tentang Perubahan atas Undang-Undang Nomor 30 Tahun 2004 Jabatan Notaris. Lembaran Negara Republik Indonesia Tahun 2014 Nomor 3. Tambahan Lembaran Negara Republik Indonesia Nomor 5491

Indonesia. Undang-Undang Nomor 24 Tahun 2009 tentang Bendera, Bahasa dan Lambang Negara serta Lagu Kebangsaan. Lembaran Negara Republik Indonesia Tahun 2009 Nomor 109. Tambahan Lembaran Negara Republik Indonesia Nomor 5035 